\title{
Mortality of Bitterbrush after Burning and Clipping in Eastern Oregon
}

\author{
ROBERT G. CLARK, CARLTON M. BRITTON, AND FORREST A. SNEVA
}

\begin{abstract}
Bitterbrush plants were burned or clipped to $5 \mathrm{~cm}$, during fall and spring, under different soil moisture conditions on 2 sites in eastern Oregon. Treated plants on the Juniperus/ArtemisiaPurshia site had an erect growth form while those on the Pinus/Purshia site were a loq-growing, decumbent form. Sprouting after treatment was similar for the 2 sites and associated forms. Burning resulted in greater mortality than clipping. Spring treatments had less mortality compared to fall treatments. Artificially watering plants did not result in a substantial reduction in mortality. Over-winter mortality of sprouts reduced the number of bitterbrush plants alive in the second growing season.
\end{abstract}

A publication summarizing recent literature on bitterbrush (Purshia tridentata) revealed that only about $10 \%$ of the citations alluded to bitterbrush response to fire (Clark and Britton 1979). The literature indicated that bitterbrush is a desirable shrub but may not be compatible with currently popular use of fire as a vegetation management tool. Response of bitterbrush to burning has been variable. In eastern Idaho it sprouted frequently but inversely with burn intensity (Blaisdell 1950, 1953). In central Oregon, Driscoll (1963) suggested that sprouting was related more to surface soil texture than burn intensity. Sprouting after wildfires was also variable in California. For example, in 5 of 13 wildfires at least $5 \%$ sprouting occurred, with a maximum of $25 \%$ (Nord 1965 ). In northern and central Utah limited sprouting occurred after wildfires (Blaisdell and Mueggler 1956). Daubenmire (1970) noted that bitterbrush was nearly always killed by wildfires in the steppes of Washington. Hormay (1943) stated that vast areas of bitterbrush have been destroyed by fire, and Billings (1952) contended that bitterbrush in the western Great Basin was permanently eradicated by fire.

Mechanical top removal appears less damaging to bitterbrush than burning. Ferguson (1972) recommended removing $33 \%$ and $50 \%$ of the canopy to stimulate growth. Mueggler and Blaisdell (1958) reported that rotobeating and railing was less damaging than burning. Blaisdell and Mueggler (1956) burned or severed bitterbrush plants $5 \mathrm{~cm}$ above ground level monthly, May through October. They found $50 \%$ and $72 \%$, respectively, of burned and severed plants sprouted, with spring treatments the least da maging. Some plants did not sprout until 13 months after treatment.

Since bitterbrush at different locations may exhibit variable genetic traits, isolating specific factors which control sprouting is difficult. However, certain environmental parameters have been implicated in sprouting. This study was conducted to evaluate some environmental parameters which may be responsible for the variation in bitterbrush response to burning and clipping.

\footnotetext{
Authors are graduate research assistant, Oregon State University, Rangeland Resource Program, Corvallis 97331; associate professor, Oregon Agricultural Experiment Station, and range scientist, USDA-ARS, Burns, Ore. 97720. Clark and Britton are now graduate research assistant and associate professor, Department of Range and Wildlife Management, Texas Tech University, Lubbock 79409.

This paper involved a cooperative effort of Eastern Oregon Agricultural Research Center and USDA-ARS, Burns, Oregon 97720. Technical Paper Number 5391. Oregon Agricultural Experiment Station.

Manuscript received December 29, 1980.
}

\section{Study Areas and Methods}

Two areas representing different plant communities were selected for study. Site I was located $30 \mathrm{~km}$ northwest of Burns, Ore., at $1,555 \mathrm{~m}$ elevation. Characteristic vegetation is the Juniperus/Artemisia-Purshia association (Fig. 1) described by Driscoll (1964). Bitterbrush growing on this site does not layer and is similar to the columnar forms described by Alderfer (1977). Soils are Lithic Zerollic Paleargids over silica and limestone coated fractured bedrock (Lindsay et al. 1969).

Site II was located $42 \mathrm{~km}$ north of Riley, Ore., at $1,585 \mathrm{~m}$ elevation. Characteristic vegetation on Site 11 is similar to the Pinus ponderosa/ Purshia tridentata (Fig. 2) association described by Daubenmire and Daubenmire (1968). Bitterbrush on this site is a low growing, decumbent form that infrequently layers. Soils are Lithic Argixerolls overlying rhyolite (U.S. Forest Service 1977). Soil texture on both sites is similar (Clark 1979). Both soils are shallow, averaging about $36 \mathrm{~cm}$ to bedrock.

Both sites were located with the High Lava Plains physiographic province described by Franklin and Dyrness (1973) on the western fringe of the Great Basin. Average annual precipitation on both sites is similar, about $30 \mathrm{~cm}$. Most of the precipitation occurs as snow during the winter months. During the study period snow persisted about 2 wecks longer on site II than on site I duc to the canopy of ponderosa pine. Bitterbrush phenological development correspondingly was initiated about 2 weeks later on site II than on site 1 .

A total of 80 bitterbrush plants on each site were randomly selected with 10 assigned to each of 8 treatments: fall clip, fall clip then water, spring clip, fall burn, fall burn then water, water then fall burn, spring burn, and control. Treatments applied later than August 1 were considered fall treatments because aerial growth had stopped and seeds had been dispersed although leaf abscission had not occurred. Fall treatments were applied during early August 1977 when $97 \%$ of the achenes had abscised. Spring treatments were applied in late March on site I and mid-April 1978 on site II when the first leaf on each fascicle was approximately $30 \%$ expanded. Earlier spring treatment was prohibited by snow cover.

Air temperature, relative humidity, and wind speed during burn treatments were determined with a battery operated fan psychrometer and a hand-held anemometer (Table 1). To produce uniform intensity on all burn treatments, plants were burned individually in a plant burner (Britton and Wright 1979). The burner was calibrated to at tain a soil surface temperature of about $260^{\circ} \mathrm{C}$ at 45 seconds. Water treat ments were applied 24 hours prior to, or immediately after burning to simulate a 5 -cm precipitation event. Water was applied as a fine mist with a calibrated positive displacement pump. With the post-burn water treatments, water was applied 1 minute after the flame subsided. Water was restricted to approximately the area of the plant burner by circular metal rings $(110 \mathrm{~cm}$ dia meter) embedded in the soil surface. Soil moisture was measured gravimetrically at the time of treatment. Clipped plants were severed approximately $5 \mathrm{~cm}$ above the soil surface to ensure removal of all photosynthetic material. 


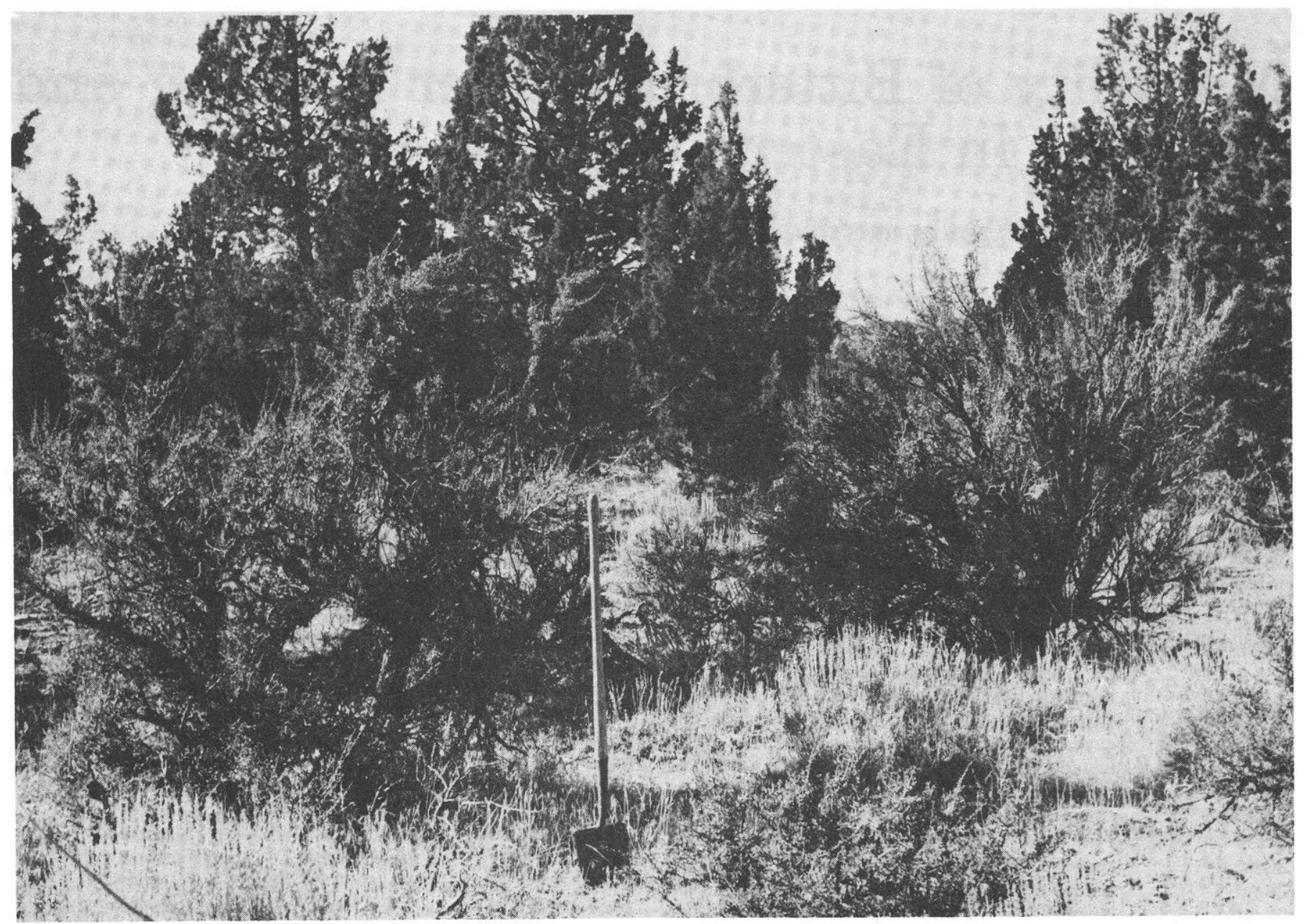

Fig. 1. Erect bitterbrush growth form on site I. Light colored shrub in foreground is Artemisia tridentata.

Treated plants were observed monthly on each site during the summer of 1978 and in June of 1979. Each plant with visible sprouts was recorded. The number of live plants in each of the 8 treat ments was subjected to Chi-square analysis to detect statistical differences.

\section{Results}

Sprouting of bitterbrush on site I and site II was similar and percent survival values could not be separated $(P<0.10)$ between sites regardless of treatment. Therefore, data were combined for site I and site II. None of the unwatered fall-burned plants sprouted (Fig. 3). Spring-burned plants exhibited a peak in sprouting by August of the first growing season. However, mortality of sprouts over-winter reduced the proportion of plants alive to $10 \%$ by June of the second growing season.

Clipped plants sprouted more frequently than burned plants. Sprouting response through time was similar to spring-burned plants with peaks occurring in July and September for fall- and spring-clipped plants, respectively. Over-winter mortality was substantial with $40 \%$ of spring-clipped plants remaining alive compared to $30 \%$ for fall-clipped plants. Regardless of treatment, spring treated plants responded better than fall treated plants.

Plants watered either before or after burning responded poorly (Fig. 4). Water treatments increased the soil moisture in the surface $5 \mathrm{~cm}$ to approximately $14 \%$ compared to an average of $5 \%$ soil moisture adjacent to unwatered plants. Some watered plants did sprout as compared to no sprouting of unwatered plants. However, only $5 \%$ of the water-then-fall-burn plants remained alive by June of the second growing season. Fall clip-then-water plants responded similarly to fall clip plants through the first growing season. Mortality over-winter was much greater for the watered plants as contrasted with the unwatered plants.

\section{Discussion}

The anticipated beneficial effects of high soil moisture on fallburned plants were not realized. Plants watered immediately after burning were expected to sprout since: (1) woody skeletons were not consumed, (2) heat was removed within 1 minute by water, (3) soil moisture approached $14 \%$, and (4) other work has indicated that fire extinguished by water resulted in increased sprouting (Blaisdell and Mueggler 1956). With spring-burned plants, sprouting was increased. This could have resulted from soil moisture. Spring soil moisture was $27 \%$ to $30 \%$, two-fold greater than with pre-watered fall burns. Also, air temperature was lower with the spring burns at $10^{\circ}$ to $12^{\circ} \mathrm{C}$.

Timing of fall treatments may be critical. Nord (1965) reported that more than $50 \%$ of plants clipped in late fall and winter sprouted, but no sprouting occurred on a similar site when plants were clipped during late summer and early fall; the difference was attributed to soil moisture.

Growth form also could have been important. Although plants on neither site were layering at time of treatment, all burned plants that sprouted on either site did so from bud masses near the axils of existing branches close to the soil but not from callus tissue on the stem as reported in Idaho (Blaisdell and Mueggler 1956).

Clipped plants displayed a response similar to burned plants 


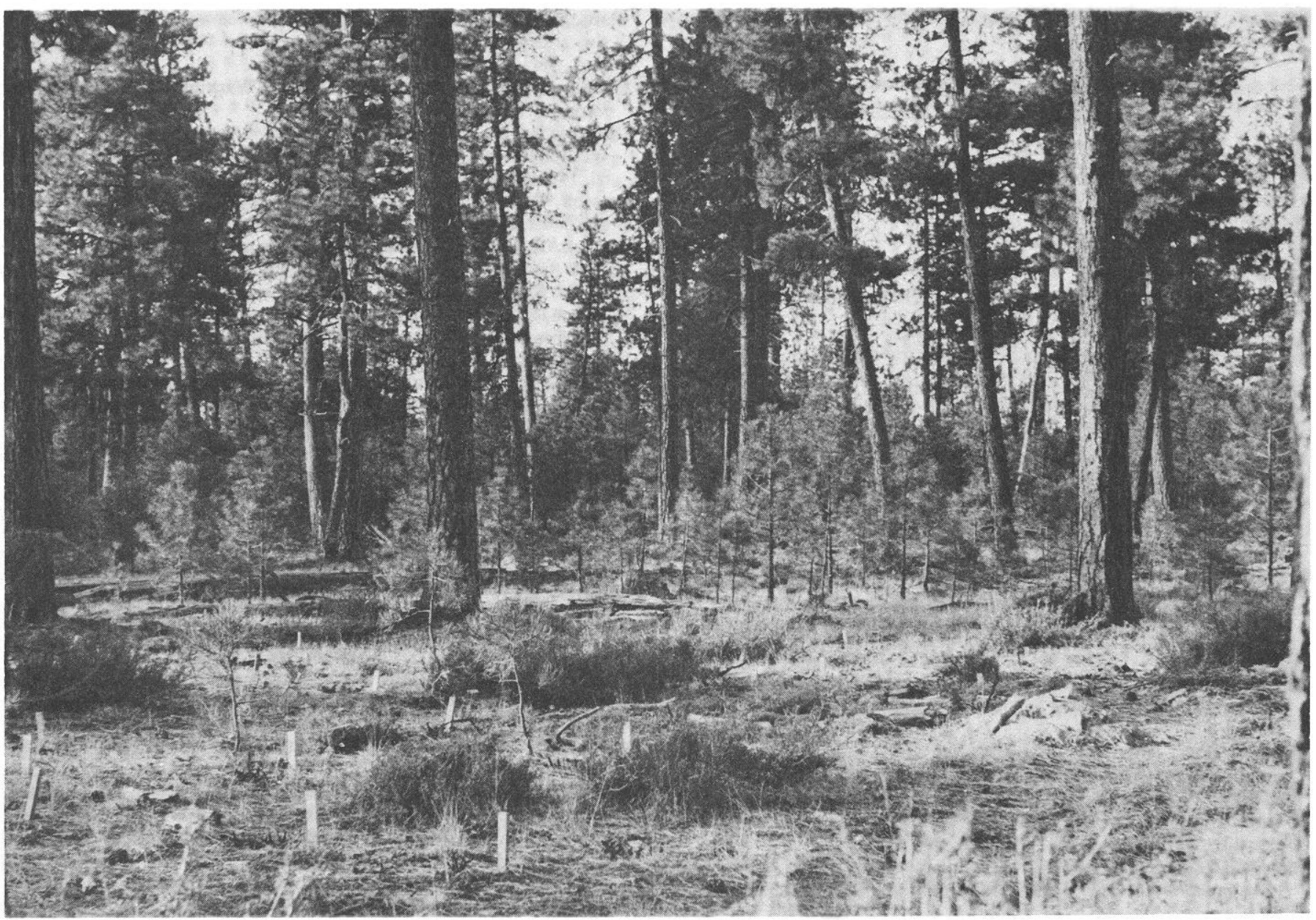

Fig. 2. Decumbent bitterbrush growth form on site II. Bitterbrush density is greatest in Pinus ponderosa openings and is reduced where pine regeneration is well established.

with respect to growth form. The decumbent form sprouted more frequently than the erect form especially with spring treatment. Other studies reporting clipping response of bitterbrush have shown differing seasonal effects and that partial top removal actually stimulated twig production (Garrison 1953, Ferguson and Basile 1966, Ferguson 1972). These reports did not present a detailed growth form description.

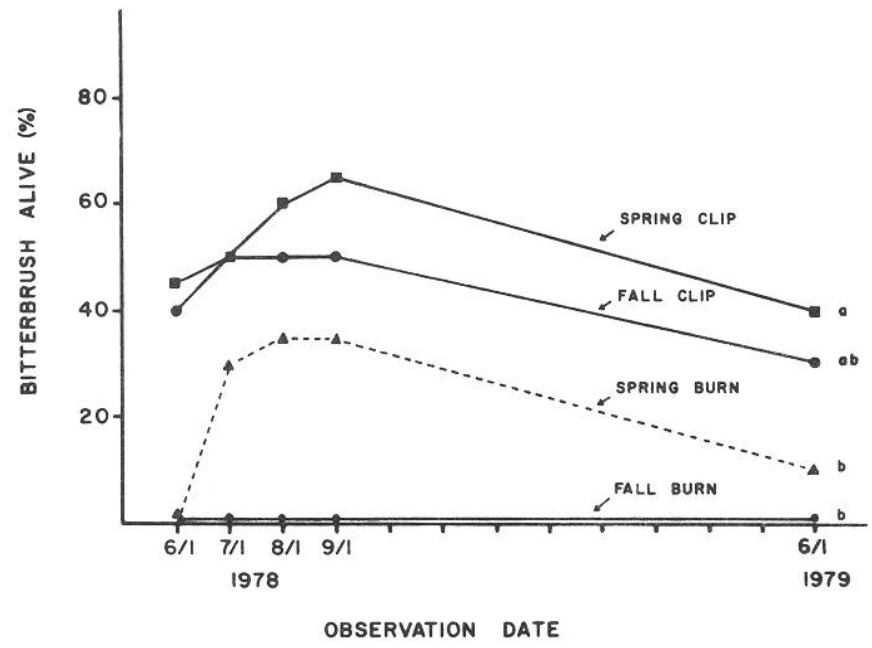

Fig. 3. Percent bitterbrush plants alive for spring and fall, clip and burn treatments in eastern Oregon. Letters following values at final observation data indicate significant differences $(\mathrm{P}<0.10)$.
Sprout mortality presents another important consideration. Even with good sprouting response, over-winter sprout mortality following 1 growing season can further reduce bitterbrush populations. These data indicate that this reduction can be substantial. In southern Idaho a similar trend in sprout mortality was observed where $33 \%$ of he burned plants and $21 \%$ of the clipped plants had died within 16 months of treatment (Blaisdell and Mueggler 1956). Bitterbrush treated or injured mechanically recovers rapidly on



OBSERVATION DATE

Fig. 4. Percent bitterbrush alive for fall treatments in eastern Oregon. On final observation, treatments were not significantly different $(\mathrm{P}<0.10)$. 
Table 1. Weather conditions during 4 burning periods on 2 bitterbrush sites in eastern Oregon.

\begin{tabular}{lcclcc}
\hline \hline & \multicolumn{2}{c}{ Fall burns } & & \multicolumn{2}{c}{ Spring burns } \\
\cline { 2 - 3 } & Site I & Site II & & Site I & Site II \\
\hline Treatment date & $8 / 3 / 77$ & $9 / 5 / 77$ & & $3 / 30 / 78$ & $4 / 13 / 78$ \\
Temperature $\left({ }^{\circ} \mathrm{C}\right)$ & 29 & 27 & & 12 & 10 \\
Relative humidity $(\%)$ & 14 & 22 & & 69 & 36 \\
Wind speed $(\mathrm{km} / \mathrm{hr})$ & $<8$ & $<8$ & & $<8$ & $<8$ \\
\hline
\end{tabular}

Authors are graduate research assistant, Oregon State University,

some sites (Ferguson and Basile 1966, Edgerton et al. 1975, Stuth and Winward 1976), although severity of treatment and site conditions affect recovery. Recovery following burning, however, is somewhat paradoxical. Data from this study confirms most reports which suggest that bitterbrush does not sprout abundantly after fire, yet fire creates litter-free sites necessary for germination of rodent-cached seed (Sherman and Chilcote 1972). Since most bitterbrush reproduction is from seed (Daubenmire and Daubenmire 1968, West 1968) rather than from sprouts or layering, reestablishment on burned areas should be enhanced by leaving intact an ample seed source or by planting.

\section{Literature Cited}

Alderfer, J.M. 1977. A tax onomic study of bitterbrush [Purshia tridentata (Pursh) DC.] in Oregon. M.S. Thesis. Oregon State Univ., Corvallis. 197 p.

Billings, W.D. 1952. The environmental complex in relation to plant growth and distribution. Quart. Rev. Biol. 27:251-265.

Blaisdell, J.P. 1950. Effects of controlled burning on bitterbrush up the Upper Snake River Plains. USDA-rS. Intermt. Forest and Range Exp. Sta. Res. Pap., Ogden. 3 p.

Blaisdell, J.P. 1953. Ecological effects of planned burning of sagebrush grass range on the Upper Snake River Plains. USDA. Tech. Bull. 1075. $39 \mathrm{p}$.

Blaisdell, J.P., and W.F. Mueggler. 1956. Sprouting of bitterbrush (Purshia tridentata) following burning or top removal. Ecology 37:365-370.

Britton, C.M., and H.A. Wright. 1979. A portable burning for evaluating effect of fire on plants. J. Range Manage. 32:475-476.

Clark, R.G. 1979. Seasonal response of bitterbrush to burning and clipping in eastern Oregon. M.S. Thesis. Oregon State Univ., Corvallis. 109 p.
Clark, R.G., and C.M. Britton. 1979. A bibliography of bitterbrush [Purshia tridentata (Pursh) DC.] annotated from 1967 to 1978. Oregon Agr. Exp. Sta. Bull. 640. 18 p.

Daubenmire, R. 1970. Steppe vegetation of Washingt on. Washington Agr. Exp. Sta. Tech. Bull. 62, Pullman. 131 p.

Daubenmire, R., and J.B. Daubenmire. 1968. Forest vegetation of eastern Washington and northern Idaho. Washington Agr. Exp. Sta. Tech. Bull. 60, Pullman. $104 \mathrm{p}$.

Driscoll, R.S. 1963. Sprouting bitterbrush in central Oregon. Ecology 44:820-821.

Driscoll, R.S. 1964. Vegetation-soil units in the central Oregon juniper zone. USDA-FS Res. Paper PNW-19. Pacific Northwest Forest and Range Exp. Sta., Portland, $60 \mathrm{p}$.

Edgerton, P.J., B.R. McConnell, and J.G. Smith. 1975. Initial response of bitterbrush to disturbance by logging and slash disposal in a lodgepole pine forest. J. Range Manage. 28:112-114.

Ferguson, R.B. 1972. Bitterbrush topping: shrub response and cost factors. USDA-FS Res. Paper INT-125. Intermountain Forest and Range Exp. Sta., Ogden. $11 \mathrm{p}$.

Ferguson, R.B., and J.V. Basile. 1966. Topping stimulates bitterbrush twig growth. J. Wildl. Manage. 30:839-841.

Franklin, J.F., and C.T. Dyrness. 1973. Natural vegetation of Oregon and Washington. USDA-FS Gen. Tech. Rep. PNW-8. Pacific Northwest Forest and Range Exp. Sta., Portland. 417 p.

Garrison, G.A. 1953. Effects of clipping on some range shrubs. J. Range Manage. 6:309-317.

Hormay, A.L. 1943. Bitterbrush in California. USDA-FS. California Forest and Range Exp. Sta. Res. Note 34, Berkeley. 13 p.

Lindsay, M.G., B.B. Lovell, J.A. Nurgren, G.H. Simonson, B.R. Thomas, and D.W. Anderson. 1969. Oregon's long-range requirements for water. Appendix I-12. Oregon State Water Resources Board, Salem. 79 p.

Mueggler, W.F., and J.P. Blaisdell. 1958. Effects on associated species of burning, rotobeating, spraying, and railing sagebrush. J. Range Manage. 11:61-66.

Nord, E.C. 1965. Autecology of bitterbrush in California. Ecol. Monogr. 35:307-334.

Sherman, R.J., and W.W. Chilcote. 1972. Spatial and chronological patterns of Purshia tridentata as influenced by Pinus ponderosa. Ecology 53:294-298.

Stuth, J.W., and A.H. Winward. 1976. Logging impacts on bitterbrush in the lodgepole pine-pumice region of central Oregon. J. Range Manage. 29:453-566.

USDA-Forest Service. 1977. Soil resource inventory. Ochoco Nat. Forest, Prineville, Ore. 289 p.

West, N.E. 1968. Rodent-influenced establishement of ponderosa pine and bitterbrush seedlings in central Oregon. Ecology 49:1009-1011. 